Journal of the Society for the Study of Architecture in Canada Le Journal de la Société pour l'étude de l'architecture au Canada

\title{
Domestic Boundaries - Arthur Erickson at Home
}

\section{Christina Gray}

Volume 43, numéro 2, 2018

URI : https://id.erudit.org/iderudit/1058035ar

DOI : https://doi.org/10.7202/1058035ar

Aller au sommaire du numéro

Éditeur(s)

SSAC-SEAC

ISSN

2563-8696 (numérique)

Découvrir la revue

Citer cet article

Gray, C. (2018). Domestic Boundaries - Arthur Erickson at Home. Journal of the Society for the Study of Architecture in Canada / Le Journal de la Société pour l'étude de l'architecture au Canada, 43(2), 3-14.

https://doi.org/10.7202/1058035ar 


\section{PRIX 2018 MARTIN ELI WEIL PRIZE}

CHRISTINA GRAY is a Ph.D. candidate at the University of California, Los Angeles. Her research focuses on the development of retail architecture in the late twentieth century. She holds a Bachelor of Fine Arts from the University of British Columbia and a Master of Architecture from the University of Toronto. Before beginning her doctoral studies, she worked for architecture firms in Vancouver and Rome.

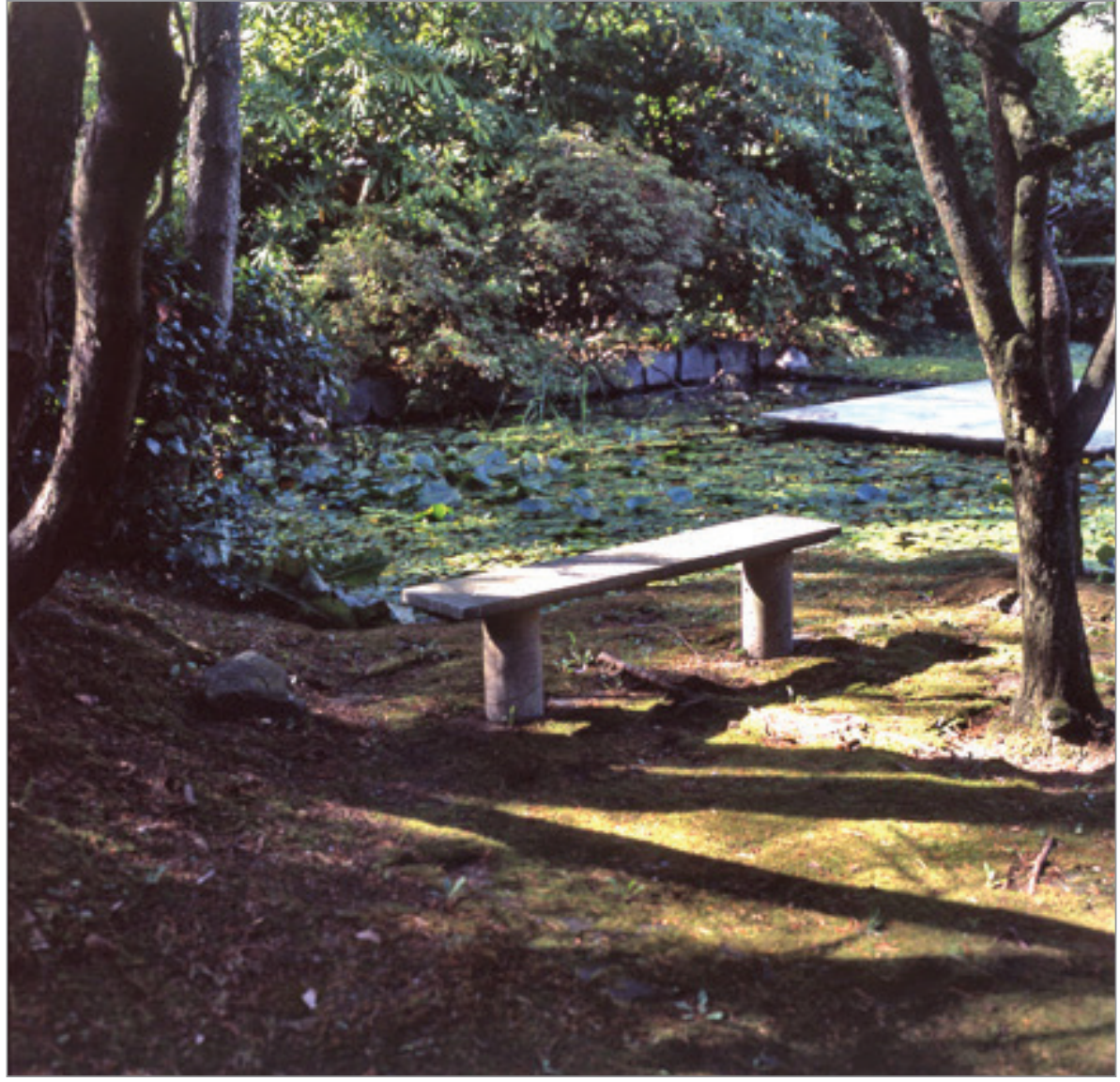

FIG. 1. ERICKSON'S GARDEN. | SIMON SCOTT.

\section{DOMESTIC BOUNDARIES - ARTHUR ERICKSON AT HOME}

n an installment of her New York Times column in 1970, architectural critic Ada Louise Huxtable once quipped: "What happens when architects build for themselves? All hell breaks loose..." This riposte could have been aimed directly at Arthur Erickson whose acclaimed architectural skills encountered numerous trials, many of his own making, when it came to the design of his own home. For the duration of his long and celebrated career, Erickson lived in a garage. In 1957 soon after he had begun teaching at the University of British Columbia, he purchased a lot of one hundred and twenty feet by sixty-six feet in the nearby West Point Grey neighbourhood of Vancouver. ${ }^{2}$ At that time, the site contained only a forty-year old garage and a small adjacent lean-to located at the edge of the rear lane, as the rest of the property had been left bare in anticipation of unrealized house construction. ${ }^{3}$ Erickson moved temporarily into this garage. Fifty-two years later, he was still living in the garage when he died in 2009. After a drawnout and high-profile bankruptcy, the garage had been declared his only asset. Throughout his career, this garage-home had remained a constant and potent reference point for a number of key narratives that fed Erickson's public persona. The underlying commonality amongst these narratives was Erickson's cavalier attitude toward established norms. In turn, this prevailing tension around rules and rule-breaking reflected a broader disquiet at the centre of Erickson's approach toward architecture. This was a conflict between the belief that architecture should be generated in response to existing conditions of context and 


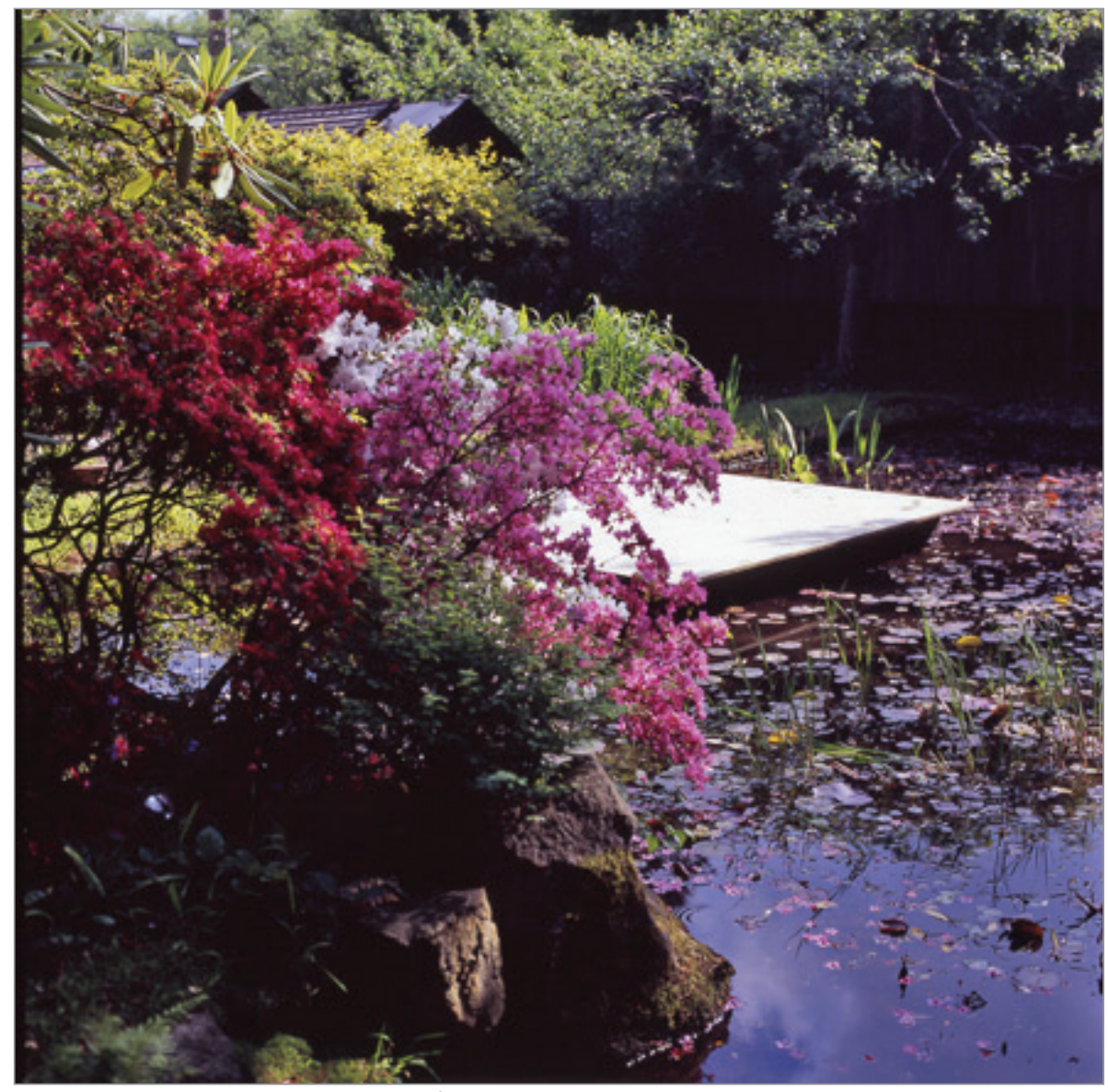

FIG. 2. POND WITH MOON-VIEWING PLATFORM. | SIMON SCOTT.

established norms or instead the belief that architecture emerged as an exceptional phenomenon that remade the rules around itself. This unresolved tension, in turn, reflected Erickson's uneasy engagement with his own position within the late modernist movement, a movement searching to relocate architectural creativity and authority. These issues lurk behind the longstanding intrigue that has surrounded Erickson's own home.

Erickson's home was often downplayed in relationship to the surrounding landscape. The garden remained the focus. The home was described by one journalist as "really more of an appendage to his rather extraordinary garden."4 on neighbouring lots, the garden was densely filled with ornamental bamboo, grasses, ferns, reeds, rhododendrons, pine azaleas, mountain laurels, and dogwoods. ${ }^{5}$ One visiting journalist recalled this mixture as a "glistening jungle." 6 With this lush abundance of planting, Erickson described his desire to present the garden "like a forest clearing in some indefinable wilderness."7 This was a wilderness of Erickson's making. When he had first acquired the site, the existing English garden had matched the neighbouring properties that tended to feature a "crisp square lawn and a rose arbour." 8 Neat herbaceous borders had furthered the orderly design. ${ }^{9}$ Erickson, however,
Eschewing the manicured lawns featured described how vegetation quickly overwhelmed the site through his own neglect, saying that as a busy young professional, he "never had time to tend to the garden." 10 He then elaborated: "The third year, the weeds took over entirely, so I got a bulldozer and told the operator to bury the garden, dig a hole, and make a hill high enough so I couldn't see the house across the street." Subsequently, he further distanced his garden from the "prim-and-proper suburban" neighbourhood gardens, when he added a moonviewing platform jutting into his newly dug pond, inspired by his longstanding interest in the Katsura Imperial Villa. ${ }^{12}$

Decades later, during the fight to preserve the site from demolition, it was again the garden that took priority. ${ }^{13}$ During the 1990s, it was a local landscape architect, Elizabeth Watts, who initiated the preservationist momentum that eventually saved the site. ${ }^{14}$ The preservationist rationale that achieved this feat consistently focused upon the historic value of the landscaping. This valorization of the landscape reflected Erickson's own descriptions of his creative process. A key touchstone for Erickson's own identification as a modernist architect was his repeated assertion that his designs were generated from their site. Repeatedly, Erickson extolled the primacy of site, saying: "Site is paramount for me because it has always been the richest source of inspiration." 15 He furthered this by stating: "architects most of all should be listeners, since architecture is the art of relating a building to its environment."16 Similarly, commentators often remarked on how Erickson's designs seemed to be derived from their surroundings, appearing to be a "direct response to a specific topography ..."17 The case of Erickson's own home demonstrated an emblematic manifestation of his complex relationship with the idea that the site 
was a generator of architectural form. In effect, Erickson had responded to the existing suburban garage by surrounding it with a landscape meant to evoke a pre-existing sylvan wilderness, producing a tension between the house and the landscape that subsumed it.

Erickson often dismissed the architectural merit of his home, for example saying, in 1965: "It was a hideous little house ..."18 In other descriptions, he could also be evasive by rebuffing the building as merely provisional. The fact that the home was a renovated garage remained clearly evident. One journalist described how "his living room has the unmistakable rectangular dimensions of a narrow, one-car garage, and so does his bedroom-study . . ."19 The tight interior space measured around six hundred square feet. ${ }^{20}$ Over time Erickson renovated some interior partition walls, but by and large he often referred to the place as "a one-roomed house." 21 Writer Edith Iglauer visited Erickson and described how the tiny interior allowed one to survey everywhere at once, saying that from one end, "[she] could see Erickson sitting and talking at a table desk strewn with books and architectural drawings." 22 Erickson's tiny bed was stuffed into "a loft accessed via a childlike ladder." ${ }^{23} \mathrm{He}$ gleefully described how he would "dive into bed from the ladder." ${ }^{24}$ Over time, he continued to tinker with this space, pushing the loft ceiling up into a skylight cut into the garage roof allowing him to "stand up to make the bed." ${ }^{25}$ In keeping with the impromptu quality of the home, there was limited heat and as a result there were some areas that were only usable during the summer months. ${ }^{26}$ Not only was the thermal comfort precarious, so too was the structure. The underlying structure was described by one journalist as merely "a primitive wood foundation." 27

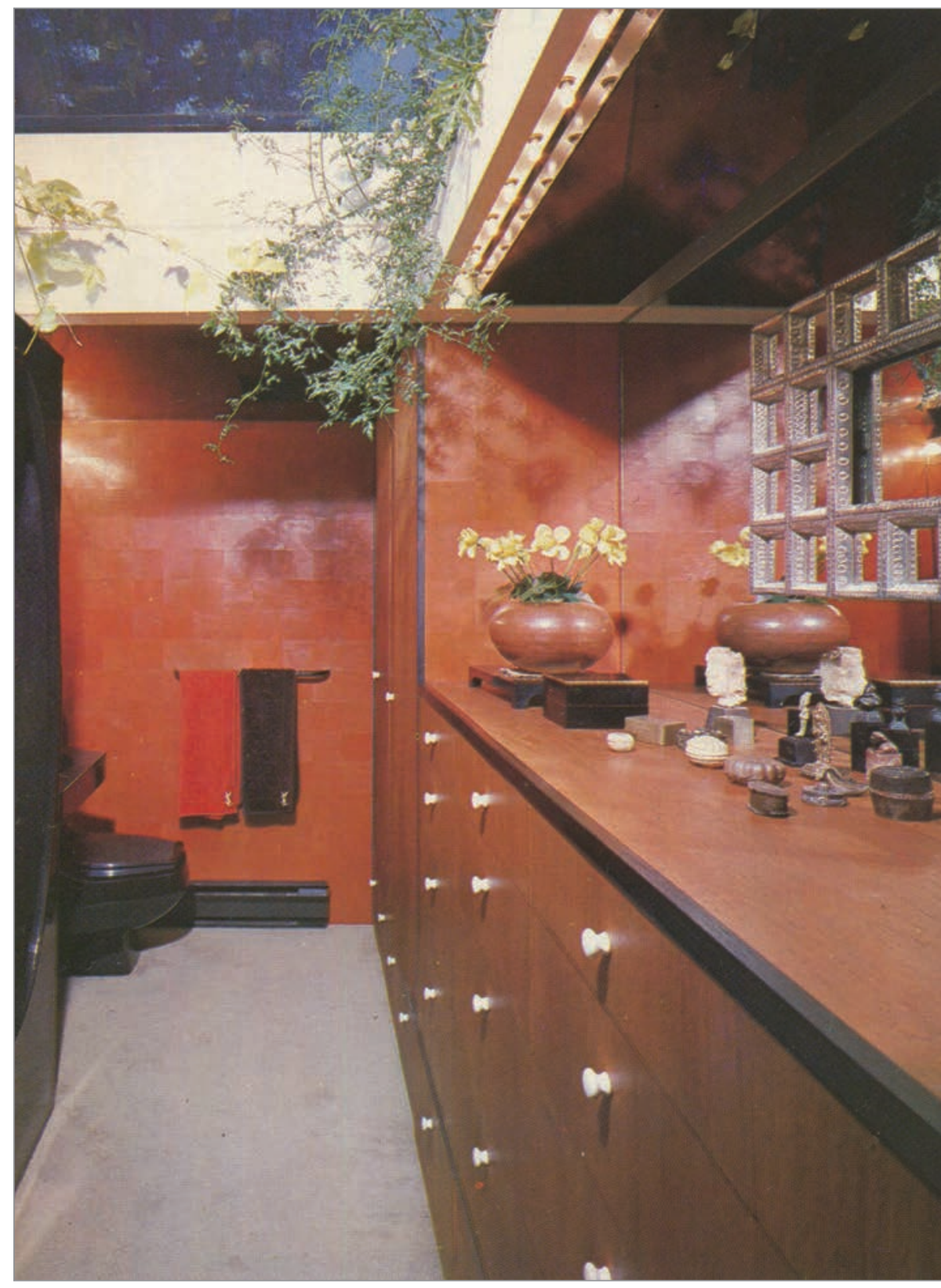

FIG. 3. WASHROOM. | SIMON SCOTT.

An eclectic mix of materials within the home reflected opportunistic and resourceful experimentation, often featuring salvaged remnants from a range of Erickson's projects. Erickson was eager to respond to materials that were already at hand. At one point, the living room walls were covered in six-inch square beige
Italian suede fabric tiles, the result of an interior decorating experiment undertaken by Erickson's partner and interior design collaborator Francisco Kripacz. ${ }^{28} \mathrm{~A}$ City of Vancouver trolley car seat sat in the living room and, when covered with pillows, acted as a sofa. ${ }^{29}$ Further seating included rosewood sofas and chairs, which 


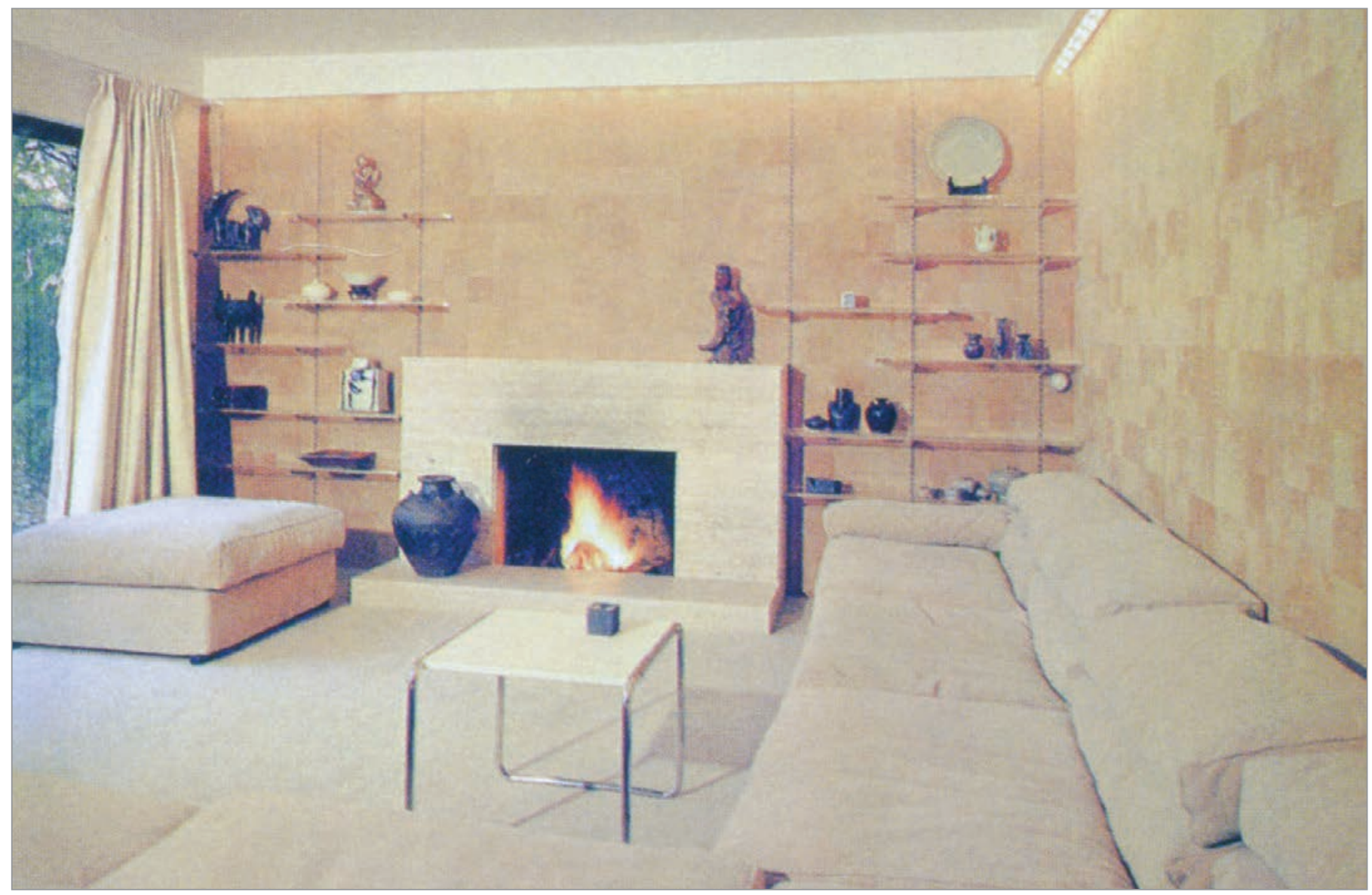

FIG. 4. LIVING ROOM. | SIMON SCOTT.

Erickson had collected on a research trip to Brazil. Marble slabs used in the interior had been salvaged by Erickson during a renovation from the urinals of the Vancouver Hotel. ${ }^{30}$ At the end of the living room stood a repurposed turn-of-the-century column. ${ }^{31}$ The improvised quality of the interior was emphasized in Erickson's telling of this column's provenance. "I set a destructive Irish sailor-handyman to taking down all the partitions, arriving only in time to save the collapse of the roof by propping it up with a wood and terracotta lonian column I'd retrieved from the demolition of a former residence." ${ }^{32}$ The bathroom similarly featured an eclectic array of materials that reflected a range of Erickson's design commissions, including a fiberglass shower, mahogany cabinets, and glazed leather-clad walls. ${ }^{33}$ The experimental application of many of the materials sometimes led to unintended consequences as when Erickson returned home to find his entire pond drained because he had chosen to line it with roofing paper. ${ }^{34}$ With a similarly relaxed attitude, Erickson embraced the patina that was left throughout the interior by his colourful social life. To this end Erickson waxed poetic about "the black shoe polished fir floors that had been badly pocked by the stiletto heels of visiting Spanish dance troupes." 35

Erickson was prone to using his curious garage-home as a narrative device that emphasized his visionary rule-breaking persona. In numerous interviews, he relayed stories of how he had contravened local bylaws, frustrated neighbours, or otherwise disregarded norms. In doing this, Erickson often proclaimed his authority as a design professional to justify the breach. Soon after acquiring the property, Erickson described how "[he] could look out of [his] living-room windows across the road and see a neighbour's very ugly front door . . .," a view which soon pushed him to dramatically re-grade the site. ${ }^{36} \mathrm{He}$ hired a man with a bulldozer to shovel the garden into a hill at the end of the property until he could no longer "see the ghastly door."37 Erickson described how this activity then 


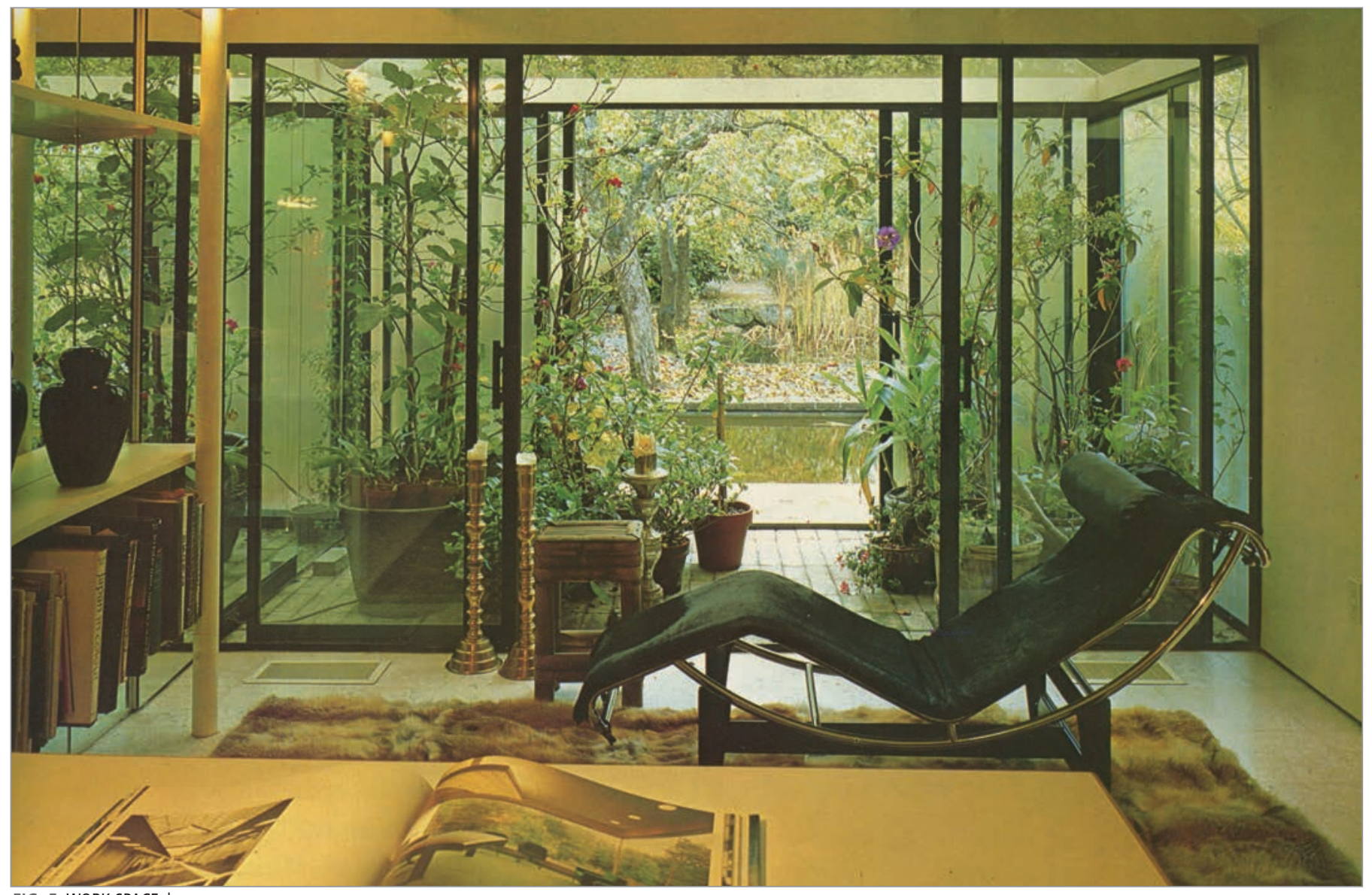

FIG. 5. WORK SPACE. | SIMON SCOTT.

attracted local attention: "Everybody in the neighbourhood thought I was excavating to build a house, and chatted with me over the picket fence, very happy to believe that they were no longer going to have a nonconformist garage dweller among them." ${ }^{38}$ Erickson continued with his description, explaining how he then flouted their expectations, not only in not building a conventional house but also in replacing the existing four-foot picket fence with a seven-foot solid cedar wall further hemming in the property. A neighbour subsequently complained to city officials that the fence contravened the city-mandated maximum fence height of four feet. Erickson attempted to compromise by cutting the fence down to six feet before the city had to intervene. ${ }^{39}$ At the subsequent City Council variance application meeting, Erickson recounted how he lost his temper when a councilman pressed him on the colour of the fence, erupting with "Surely with my background, I should be the judge of that!" 40 When compelled again by the city to paint the offending fence, Erickson threatened to hire a graffiti artist. ${ }^{41}$ Eventually, he agreed to cut the unpainted fence down by a further three or four inches, just as he encouraged his thick bushes and trees to grow ever taller. ${ }^{42}$ Obscuring bylaw infringements with thick vegetation was a strategy not limited to the property line. Erickson also built over the exterior space between the garage and adjacent lean-to in order to create one continuous structure, joined by this skylit connection. A carefully cultivated grapevine covered this illegal link..$^{43}$ Since Erickson was living in the intended garage, whenever his habit of renting cars left him with a vehicle to park, he would use the back lane as his parking space, a practice that was frowned upon by the city and irked some neighbours. ${ }^{44}$

Erickson's approach toward the wildlife that was attracted to his densely planted garden similarly generated neighbourly attention. Architect and friend Barry Downs described how Erickson was ruthless with his BB gun, unafraid of shooting at the herons that threatened to eat the fish 


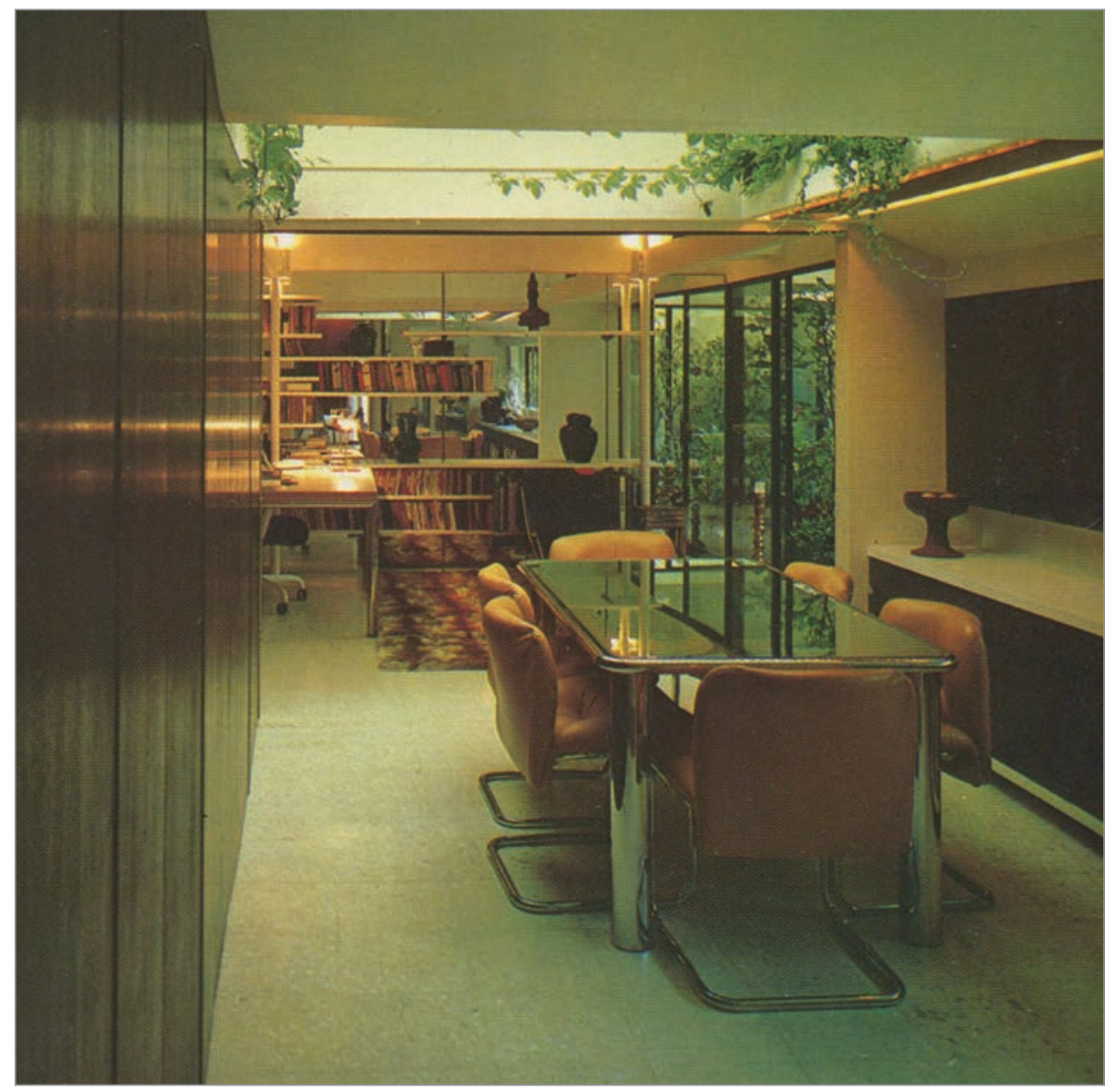

FIG. 6. DINING SPACE. | SIMON SCOTT.

in his pond. Erickson admitted to Downs that once he had "shot through the neighbour's window accidentally." ${ }^{45}$ Additionally, late one night Erickson was attempting to chase some pesky raccoons away from his fishpond with a flashlight when he called a friend who owned a gun for further backup. His neighbours reported seeing waving flashlights and hearing gunshots emerging from the dense foliage and soon a squadron of police cars was on the scene. ${ }^{46}$ In his own defense, Erickson then asked a journalist: "Have you ever tried standing in pyjama pants, trying to explain a vendetta with raccoons to a curious policeman at 2 a.m.?"47

But these disturbances and contraventions were all minor infractions compared regulations, over time he developed a far more antagonistic sense that architects should be given more authority to adapt planning to architecture. ${ }^{49}$ This growing sense of architectural exceptionalism in the face of planning regulation was illustrated when Erickson declared in 1980: "Social and economic theories? Bound to disaster. There's only one law. Call it Erickson's Law." ${ }^{50}$ Architect and longtime employee Bing Thom corroborated Erickson's growing antagonism toward regulatory compliance when he observed: "Architecturally, he's always pushing the problem to its limits. He's always pushing the client to the limit. He's always pushing governments to their limit. Regulatory authorities to their limit." ${ }^{51}$ Erickson prepared a text in 1988 in which he described how architecture naturally existed in a state of defiant conflict with its urban context. He argued that the challenge was to make the building appear as if the context had been shaped in response to the building, instead of the other way around. "Since urban surroundings are usually given, the trick is to make them appear as if they were made for the building. Even though the building is a new intruder, it can appear as though it has orchestrated its own skyline, its own approaches and their unfolding spaces." ${ }^{22}$ This sleight of hand in which architecture appeared to respond to its environment, but in which it effectively recreated its environment in its own image, was a trick Erickson claimed to have learned from his modernist predecessors. ${ }^{53}$

In addition to flouting urban planning regulations, Erickson also used his home to project his crossing of social expectations. His home soon became associated with bacchanalian parties amongst his vast acquaintances, his neighbours, and the public at large, creating a platform for his image as the intriguing man at the centre of an expansive and 


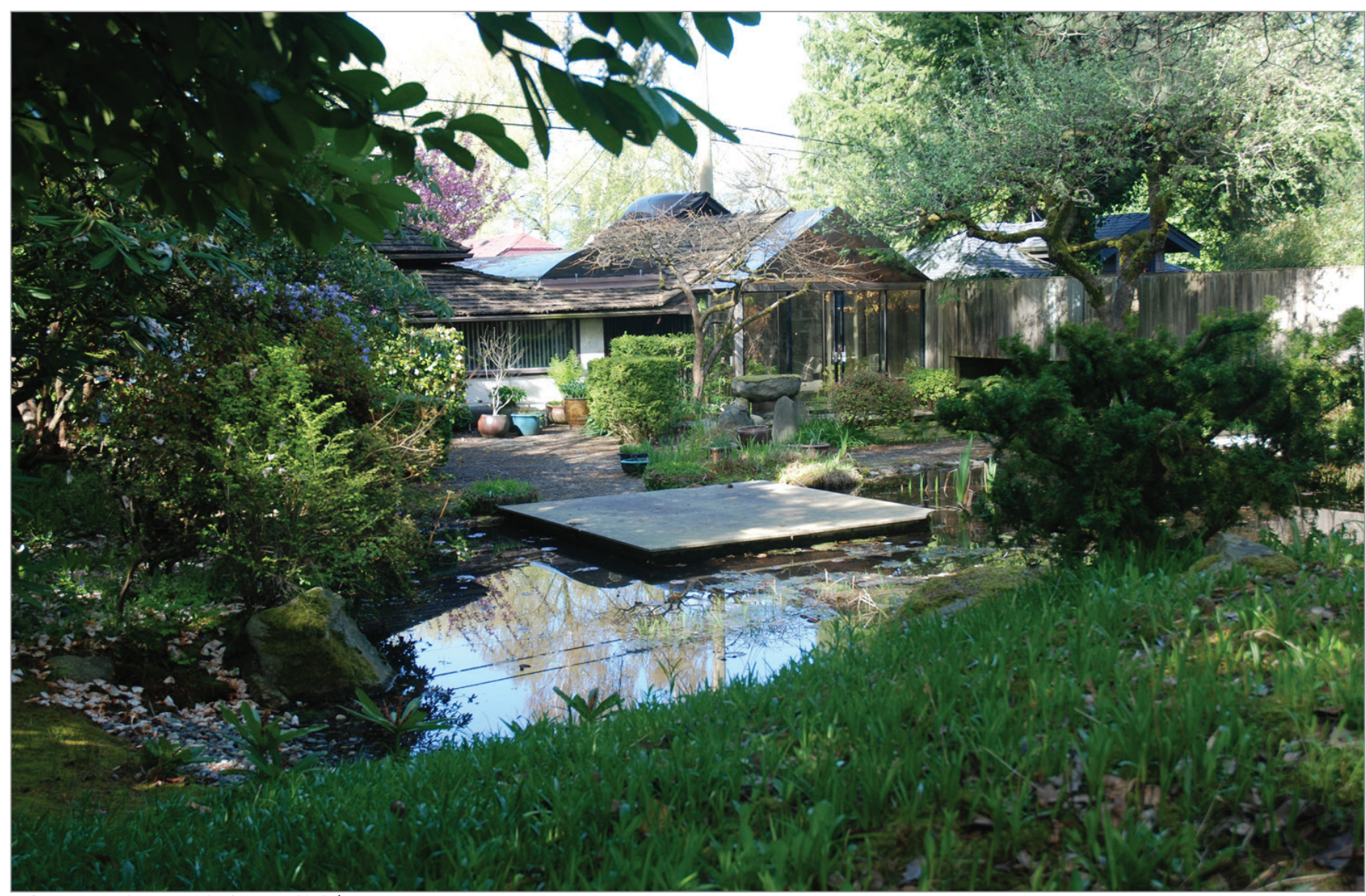

FIG. 7. VIEW FROM THE BACK GARDEN, 2018. | CHRISTINA GRAY.

cultivated social sphere. The bon vivant Erickson was described in a local paper as someone who "appears as predictably in the society columns as canapés at the soirees he frequents." ${ }^{54}$ The house parties grew legendary through retellings, often featuring well-known guests such as Prime Minister Pierre Elliott Trudeau. ${ }^{55}$ Newspapers reported stories of anthropologist Margaret Mead reading to spellbound attendees at one event. Journalists similarly detailed another party in 1967 for the London Royal Ballet where Rudolf Nureyev danced around Erickson's pond, which had been specially filled with black swans, before jumping into the water in the buff for some inspired skinny dipping. ${ }^{56}$ Illuminated by Japanese paper lanterns, another party was described as having been choreographed around a climactic moment featuring two musicians playing traditional Japanese instruments, accompanying Erickson as he released a jar of fireflies that had been flown in from Eastern Canada earlier that day. ${ }^{57}$ Erickson described using his home and garden as a malleable stage set for such elaborate events, describing: "If I have a lavish party, I put musicians across the water, and it's as if they were playing from an island over the sea." 58 Another journalist described how "[t]he buffed and the beautiful once vied for invitation to parties hosted by him and his longtime partner, Francisco Kripacz . . ."59 The architectural press joined in such descriptions with Canadian Architect magazine telling of "many joyous parties, and more than a few tipsy artists plunged happily into the hot tub." ${ }^{60}$ The interest in Erickson's social life was widespread. His biographer described how "[of] special interest to people in Vancouver were the elaborate themed parties he hosted in his bachelor's garden with sometimes as many as 200 guests looking for parking." ${ }^{61}$ For an intrigued public, the non-traditional approach embodied by Erickson's home seemed to match the vibrant social sphere contained behind those high hedges.

Erickson's makeshift home also reinforced narratives about the modern architect as a global peripatetic figure who did not 


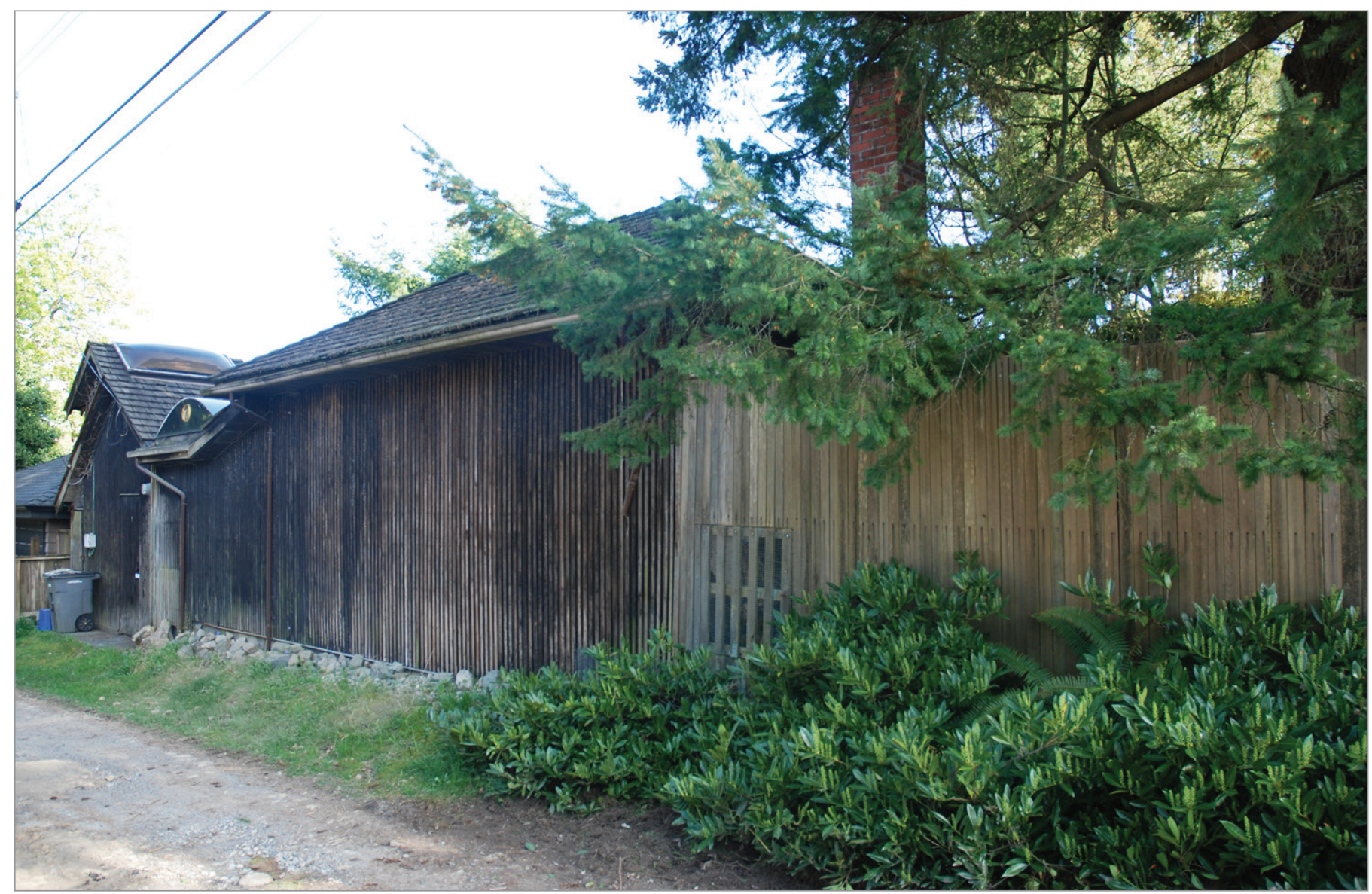

FIG. 8. VIEW FROM THE BACK LANE, 2018. | CHRISTINA GRAY.

require a home, merely a pied-à-terre from which to briefly touch base between world travels. In numerous interviews Erickson dismissed his home as merely "a place to camp," as his "real home [was] in the world." 62 The modest quality of the home had Erickson describing how pleased he was that "this place [was] so convenient, because [he could] shut it and leave." ${ }^{63} \mathrm{He}$ explained how his frenetic professional schedule had created a strong sense of restlessness: "I find that about every fourth day or so I become impatient and it's time to move along." ${ }^{64}$ He claimed that he had not stayed more than ten consecutive days in place since 1965. ${ }^{65}$ One journalist stated, in 1985: "It is possible, given his legendary jet-setting and near-compulsive travels, that Arthur Erickson has no home these days . . ."66 When a journalist interviewed Erickson in his home, she described how the ever-frenetic Erickson owned a beautiful Le Corbusier lounge chair but that he only "likes to rest in it briefly ... before he goes out to dinner." 67 Furthering this mythology of a modern architect who was at home in the world, Erickson, once listed in the Canadian Who's Who, said that his twin "recreations" were architecture and travelling. ${ }^{68}$

Constant restlessness was not merely a condition of Erickson's living arrangements, it was also thoroughly embedded in his design practice. Citing his desire to work on schematic designs undisturbed, Erickson characterized the extreme isolation of an airplane cabin as the ideal workspace. One interlocutor described how he worked: "Frequently on an airplane he sketches with his fine point black felt tip pen secure against air pressure on standard $81 / 2 \times 11$ vellum sheets, comfortably accommodated on his tray table." 69 Erickson described in 1978 how his constant travel often made him unavailable to his employees but that this sense of constant postponement suited his design ethos, saying: "My work method is crudely described as 'by the seat of the pants' ... This becomes sometimes confusing and disturbing to those working around me since it means postponing decisions and 


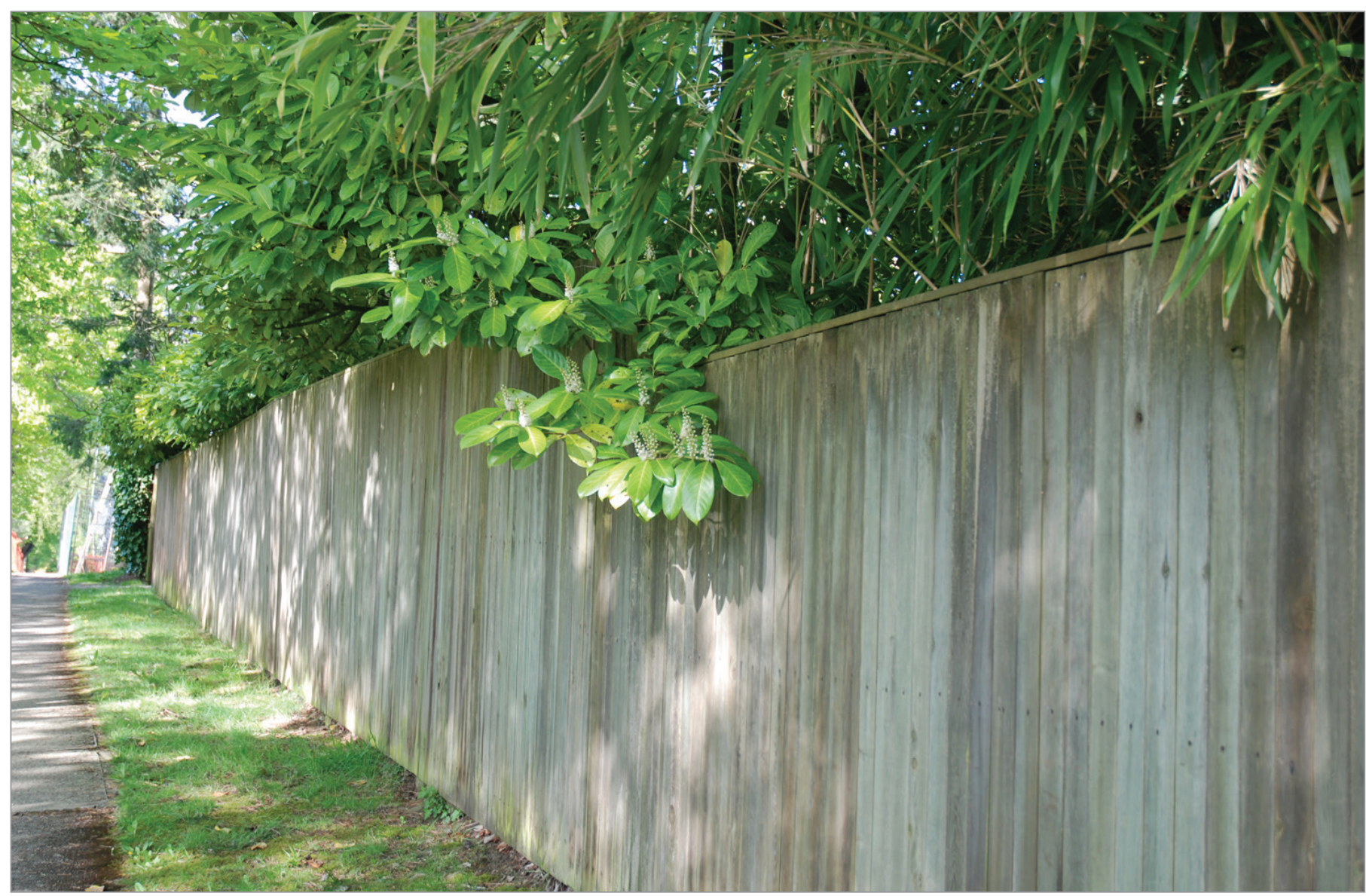

FIG. 9. VIEW FROM THE SIDEWALK, 2018. | CHRISTINA GRAY.

pursuing explorations for as long as possible without making any emotional, intellectual or sensible commitment."70 This absenteeism posed a challenge for Erickson's collaborators as this comment from his long-time employee and protégé Bing Thom makes clear: "Arthur, it was said, was never going anywhere, he was always leaving." ${ }^{11}$ But regardless of its efficacy, basing his design methodology in this form of cosmopolitan restlessness became a selling point for him as he attracted a more international clientele. Erickson described hosting a reception at his home in 1976 for one hundred and fifty people that included a Saudi Arabian prince who happened to be in Vancouver. He described taking the incredulous prince on a tour of his tiny home, with the astonished prince laughing out loud when he saw the makeshift ladder leading to Erickson's bed tucked above a storage area. Two nights later, the prince invited Erickson to his own reception, whereupon he continued the running joke by inviting Erickson, should he feel tired during the party, to climb up into the canopy above the bar to have a rest. $^{72}$ Erickson had clearly cemented his reputation as a cosmopolitan traveler amongst potential clientele. Soon after, he began several Middle Eastern design commissions, including the un-built Centre for Science and Technology in Saudi Arabia.

Erickson's home also reinforced his image as an architect still in touch with his modest background despite his ability to hobnob in elite circles. ${ }^{73}$ Public intrigue around his social sphere had begun to sour in some quarters by the late 1970s and early 1980s, with some observers beginning to gripe about his "King Arthur and His Court regal public image." ${ }^{74}$ As the impression of Erickson's profligate ways grew wider, he more frequently mentioned both his modest middle-class childhood and his home's modest origins in lectures and interviews. ${ }^{75}$ The incongruity of this mixture was particularly striking during the 1970s when Erickson was beginning a number of large-scale projects in the Middle East. The architectural photographer Simon Scott recalled: "Gulf sheikhs pulling up in big black limousines 
and being astounded at the simplicity of his home."76

Ultimately, the contradictions and ironies embedded within the narrative web surrounding the garage-home and its proprietor were unsustainable. The makeshift home built on a tantalizing mythology of cunning improvisation and cavalier rule flouting was not solid enough to carry the full weight of its own success. By the early 1990s it became clear that Erickson had overextended himself. When the fall came, it was humiliatingly public. Newspaper headlines screamed: "Arthur Erickson, the High Rolling World Famous Architect from Vancouver is Broke."77 In 1992, Erickson declared bankruptcy with personal debts of ten million five hundred dollars with a list of three hundred creditors. ${ }^{78} \mathrm{His}$ home was listed as his only asset, but it too had been "hopelessly over mortgaged" in the words of one of the officials handling the bankruptcy..$^{79}$ When the paperwork emerged, many were incredulous that Erickson had managed to carry three million four hundred dollars in mortgages on a property that was only valued at four hundred and fifty thousand dollars. ${ }^{80}$ One journalist offered that such audacious cunning at least deserved accolades for the "work, thought and experimentation in the realm of financial ingenuity." 81 Though partly obscured, the financial strain had been building for some time. In 1989 Erickson had closed his Toronto office leaving creditors and lawsuits in his wake. ${ }^{82}$ In 1991 he had closed his Los Angeles office similarly under a cloud of debts. ${ }^{83}$ All of the charms that had been embodied by his lifestyle turned against him. Foreshadowing his endemic financial problems, Erickson had told a journalist in 1985 that "travel and telephone costs [were] among the larger expenses of his business." ${ }^{84}$ Once the bankruptcy was underway, Erickson dismissed the financial troubles by calling himself an "idiot savant," unable to square business with architecture. ${ }^{85}$ Others suggested that it was Erickson's willingness to use company funds for his high-maintenance lifestyle that had been at the root of the problem. The more forgiving were willing to explain this financial problem as inherently linked to architecture, as in Bing Thom's explanation that "You have to drink the fine wine your millionaire client drinks, even though you don't have those millions. That's a dilemma for architects of his stature." 86

Cultivated over decades, Erickson projected an intricate entanglement of narratives around his home that served varying purposes in sustaining his public persona. The long arc of his career and his shifting needs and attitudes meant that these narratives sometimes conflicted with and compounded one another. Within the centre of this narrative swirl, the building remained a touchstone to Erickson who declared in 1992: "The house is very much a part of me. It's one of the constants of my life." ${ }^{87}$ At the core of the stories he told about his own living arrangements was a rich well of tension between Erickson's dueling understanding of architecture as both reactive and projective. This irreducible tension was manifest in his lifelong hedging over whether he would ever complete the project and build himself a home rather than continue to live in the garage. At one point, Erickson quipped that he was merely building up his savings, saying he "still [could not] afford an Erickson house." 88 At another point, he suggested that he might rather hire another architect to complete the project for him. ${ }^{89}$ Observers wondered if perhaps Erickson had attempted to design a home for himself, but had tragically given up under the immense pressure of expectation. ${ }^{90}$ Within this rich web of speculation and narrative, Arthur Erickson remained at the centre, enticing visitors with his curiously adapted garage-home while projecting the tantalizing promise of architecture yet to come.

\section{NOTES}

1. Huxtable, Ada Louise, 1970, "The Architects Design Their 'Dream' Home,'" New York Times, July 12, p. 88.

2. Erickson, Arthur, 1978, "The House at 4195 West $14^{\text {th }}$ Avenue, Vancouver, British Columbia," n.d., Speeches by Arthur Erickson (publisher not identified), UBC Library, NA749. E75 A5; Liscombe, Rhodri,1985, "Critical Biography," Arthur Erickson - Selected Projects 1971-1985, exhibition catalog, New York, Center for Inter-American Relations, p. 8.

3. Erickson, ibid.

4. Ditmars, Hadani, 2013, "The Former Home of Late Architect Arthur Erickson Faces an Uncertain Future," Wallpaper, March 1.

5. Fraser, Linda and Michelangelo Sabatino, 2013, Arthur Erickson: Layered Landscape, Halifax, Dalhousie University Press, p. 12.

6. Iglauer, Edith, 1981, Seven Stones - A Portrait of Arthur Erickson, Architect, Seattle, University of Washington Press, p. 30.

7. Fraser and Sabatino, Arthur Erickson: Layered Landscape, p. 10.

8. Haden, Bruce, 1995, "Exotic Battleground: The Deceptive Tranquility of Arthur Erickson's Garden Belies a Three-Decade-Long Struggle Against Pesky Bureaucrats and Roving Racoons," Canadian Architect, vol. 40, no. 11, p. 42.

9. Erickson, "The House at 4195 West $14^{\text {th }}$ Avenue," op. cit.

10. Ghanim, Zak, 1994, "Interviews by Zak Ghanim with Arthur Erickson," [https://www.youtube. com/watch?v=X0upz3gKndk], last accessed January 2018.

11. Iglauer, Seven Stones, p. 33.

12. Whysall, Steve, 1993, "Battle Blooms Over Erickson's Abode: If You Think the Architect Was Great, You Probably Favor Preservation," Vancouver Sun, July 24, p. D19. 
13. Dafoe, Chris, 1997, "Donors Come to Rescue of Erickson House," Globe and Mail, January 28, p. D2.

14. She was an early initiator in preserving the site in 1993 by establishing the Citizens to Preserve the Arthur Erickson House \& Garden Foundation.

15. Fraser and Sabatino, Arthur Erickson: Layered Landscape, p. 6.

16. Freedman, Adele, 1980, “In Erickson's Eden, An Architect Can Improve on Nature," Globe and Mail, October 4.

17. Liscombe, "Critical Biography," p. 9.

18. Reif, Rita, 1965, "Home: 2 Garages and a Lean-to," New York Times, September 14, p. 28.

19. Iglauer, Seven Stones, p. 28.

20. Whysall, "Battle Blooms Over Erickson's Abode," op. cit.

21. Erickson, "The House at 4195 West $14^{\text {th }}$ Avenue," op. cit.

22. Iglauer, Seven Stones, p. 34.

23. Ditmars, "The Former Home of Late Architect Arthur Erickson," op. cit.

24. Reif, "Home: 2 Garages and a Lean-to," op. cit.

25. Erickson, "The House at 4195 West $14^{\text {th }}$ Avenue," op. cit.

26. Ibid.

27. Ditmars, "The Former Home of Late Architect Arthur Erickson," op. cit.

28. Erickson, Arthur, 2015, Francisco Kripacz, Vancouver, Erickson Estate, p. 4.

29. Reif, "Home: 2 Garages and a Lean-to," op. cit.

30. Erickson, "The House at 4195 West $14^{\text {th }}$ Avenue," op. cit.

31. Reif, "Home: 2 Garages and a Lean-to," op. cit.

32. Erickson, "The House at 4195 West $14^{\text {th }}$ Avenue," op. cit.

33. Ditmars, "The Former Home of Late Architect Arthur Erickson," op. cit.

34. Reif, "Home: 2 Garages and a Lean-to," op. cit.

35. Erickson, "The House at 4195 West $14^{\text {th }}$ Avenue," op. cit.
36. Fraser and Sabatino, Arthur Erickson: Layered Landscape, p. 13.

37. Ibid.

38. Iglauer, Seven Stones, p. 33.

39. Edmonds, Alan, 1970, "The Architect Who Thinks People Matter More Than Buildings," Maclean's, June, p. 44

40. Iglauer, Seven Stones, p. 35.

41. Haden, "Exotic Battleground," op. cit.

42. Iglauer, Seven Stones, p. 35. The fence debacle is also described in: CP, 1985, "Architect Makes His Own Rules," Globe and Mail, July 13.

43. Haden, "Exotic Battleground," op. cit.

44. Iglauer, Seven Stones, p. 28.

45. Lazarus, Eve, 2015, "Arthur Erickson's House and Garden are on the Endangered List," Every Place Has a Strong Blog, January 10, [http://evelazarus.com/arthur-ericksonshouse-and-garden-are-on-the-endangeredlist/], accessed May 27, 2018.

46. Haden, "Exotic Battleground," op. cit.

47. Edmonds, "The Architect Who Thinks People Matter," p. 49.

48. Erickson, "The House at 4195 West $14^{\text {th }}$ Avenue," op. cit.

49. Vancouver City Council Archives, Meeting Minutes, May 22, 1963, p. 339, City of Vancouver Archives.

50. Freedman, "In Erickson's Eden," op. cit.

51. Kines, Lindsay, 1991, "Beautiful Things, Beautiful Spaces," Vancouver Sun, July 27, p. D1.

52. Erickson, Arthur, 1988, The Architecture of Arthur Erickson, Vancouver, Douglas \& Mclntyre, p. 19.

53. Ibid.

54. Hawthorn, Tom, 1992. "Arthur Erickson the High-rolling World Famous Architect from Vancouver is Broke," Calgary Herald, March 15, p. B2.

55. Stouck, David, 2013, Arthur Erickson: An Architect's Life, Madeira Park, Douglas \& Mclntyre, p. 128.

56. Ditmars, "The Former Home of Late Architect Arthur Erickson," op. cit. This Rudolf Nureyev story was also referenced in: Whysall, "Battle Blooms Over Erickson's Abode," op. cit.
57. Stouck, Arthur Erickson: An Architect's Life, op. cit.

58. Iglauer, Seven Stones, p. 33.

59. Brewster, Hugh, 2009, "Remembering Arthur Erickson," Xtra, June 3, p. 37.

60. Haden, "Exotic Battleground," op. cit.

61. Stouck, Arthur Erickson: An Architect's Life, op. cit.

62. Peck, Stacey, 1982, "Home Q \& A," Los Angeles Times, June 20, p. M32.

63. Iglauer, Seven Stones, p. 30.

64. Peck, "Home Q \& A," op. cit.

65. Iglauer, Seven Stones, p. 20.

66. Godfrey, Stephen, 1985, "For Erickson, Home is Where the Work Is," Globe and Mail, October 19, p. D13.

67. Iglauer, Seven Stones, p. 34.

68. Id., p. 20.

69. Liscombe, "Critical Biography," p. 6

70. Id., p. 10.

71. Hawthorn, "Arthur Erickson, the High-rolling World Famous Architect," op. cit.

72. Peck, "Home Q \& A," op. cit.

73. Hawthorn, "Arthur Erickson, the High-rolling World Famous Architect," op. cit.

74. Lamb, Jamie, 1992, "Erickson Home a Monument to Ingenuity in Creative Financing," Vancouver Sun, June 25, p. B1.

75. Sabatino, Michaelangelo, 2014, "Arthur Erickson - Money, Media and Canadian Architecture," Perspecta, vol. 47, August, p. 73.

76. Ditmars, "The Former Home of Late Architect Arthur Erickson," op. cit.

77. Hawthorn, "Arthur Erickson, the High-rolling World Famous Architect," op. cit.

78. Smith, David, 1992, "Noted Architect Files for Personal Bankruptcy: 300 Unsecured Creditors Listed," Vancouver Sun, February 26, p. D4.

79. Ibid.

80. Lamb, "Erickson Home a Monument to Ingenuity," op. cit.

81. Ibid.

82. Kines, "Beautiful Things, Beautiful Spaces," op. cit. 
83. Ibid. This is also discussed in: Walters, Donna, 1991, "The Collapse of an Architectural Pillar Jolts LA," Los Angeles Times, July 15, p. D1.

84. CP, "Architect Makes His Own Rules," op. cit.

85. Hawthorn, "Arthur Erickson, the High-rolling World Famous Architect," op. cit.

86. Ibid.

87. Hume, Christopher, 1992, "Is This a Ruined Man?," Toronto Star, March 15, p. D1.

88. CP, "Architect Makes His Own Rules," op. cit.

89. Ibid.

90. Mulgrew, Ian, 1997, "Erickson's Heritage Site Saved by Donors: 'A Magical Poetic Spirit,'" Vancouver Sun, January 24, p. B1. 